\title{
The bottom line is completeness of revascularization!
}

\author{
Suk Jung Choo, MD, PhD
}

See related article on pages 1027-33.

In this issue, the long-term influences of conduit choice (bilateral internal thoracic artery [BITA] vs single left internal thoracic artery) and pump strategy (on-pump vs offpump) on survival outcomes after coronary artery bypass grafting $(\mathrm{CABG})$ are reported. ${ }^{1}$ Baseline variables were adjusted by propensity matching, resulting in 4 equally matched groups of 353 patients (BITA on-pump CABG, BITA off-pump CABG, left internal thoracic artery [LITA] on-pump CABG, and LITA off-pump CABG) for a total cohort of 1412 patients out of the initial 6666 patients undergoing isolated CABG. During the mean follow-up of 10.5 years, the BITA groups showed a significant 15-year survival advantage relative to the single LITA groups, at $72.6 \%$ versus $62.8 \%$. Interestingly, the pump strategy had no significant influence on the survival outcomes, which was counterintuitive in light of the recent intermediate- to long term publications in the Veterans Affairs Randomized On/Off Bypass (ROOBY) trial, ${ }^{2}$ a study by Kim and colleagues, ${ }^{3}$ and a meta-analysis by Takagi and coworkers, ${ }^{4}$ which reported higher adverse composite outcomes of allcause mortality, revascularization, and nonfatal myocardial infarction with off-pump CABG. A recent Danish On-pump Versus Off-pump Randomization Study (DOORS) trial subgroup analysis ${ }^{5}$ showing significantly inferior angiographic patency with off-pump compared with on-pump CABG at 6 months $(79 \%$ vs $86 \% ; P=.01)$ further highlighted the technical challenges with off-pump surgery in achieving optimal anastomoses. In contrast, the 1 year Coronary Artery Bypass Surgery Off or On Pump Revascularization Study (CORONARY) trial outcomes and a recent substudy of the Arterial Revascularization Trial (ART), ${ }^{6,7}$ both of which were 1-year studies, showed comparable survival and composite of major adverse outcomes. It should be noted, however, that the divergence in long-term survival outcomes is usually reported to appear beyond the first year. In a long-term study by Synnergen and associates

From the Department of Thoracic and Cardiovascular Surgery, Asan Medical Center, Ulsan University School of Medicine, Seoul, Republic of Korea.

Disclosures: Author has nothing to disclose with regard to commercial support.

Received for publication Jan 14, 2015; accepted for publication Jan 14, 2015; available ahead of print Feb 11, 2015.

Address for reprints: Suk Jung Choo, MD, PhD, Asan Medical Center, Ulsan University School of Medicine, Thoracic and Cardiovascular Surgery, 388-1 Poongnap-dong Songpa-gu, Seoul, 138-736 Republic of Korea (E-mail: sjchoo@ amc.seoul.kr).

J Thorac Cardiovasc Surg 2015;149:1034-5

$0022-5223 / \$ 36.00$

Copyright (C) 2015 by The American Association for Thoracic Surgery

http://dx.doi.org/10.1016/j.jtcvs.2015.01.024

comparing 8461 patients undergoing on-pump CABG and 947 undergoing off-pump CABG during 5 years, the influence of pump strategy was not significant as long as the completeness of revascularization was not compromised. Off-pump CABG was, however, associated with significantly greater incomplete revascularization. ${ }^{8}$ The study in this issue of the Journal ${ }^{1}$ surprisingly showed significantly more distal anastomoses with off-pump versus on-pump CABG, at 3.60 and 3.45 , respectively $(P=.001)$, but no significant differences in long-term survival outcomes between the 2 pump strategies. This finding was somewhat at odds with the multivariate analysis, which showed an association between fewer grafts and poorer long-term survival. At the least, the data clearly show that the investigators in this study are expert in off-pump CABG and were not limited by the pump strategy in achieving comparable degrees of revascularization. Puskas and coauthors ${ }^{9}$ have also shown excellent outcomes with off-pump CABG with comparable degrees of revascularization completeness to pump CABG. In the "real world," however, where there is a constant stream of newcomers arriving at the scene facing critical learning curves for off-pump CABG, an assumption of comparable degrees of revascularization being achieved independent of the pump strategy is not a realistic expectation, especially when fewer anastomoses with OPCAB are reported even among highly experienced surgeons. The evidence thus far therefore seems to weigh in favor of generally recommending on-pump CABG as the standard of practice for CABG.

Since the landmark study by Loop and colleagues, ${ }^{10}$ which showed significantly improved 10 -year survival outcomes with LITA to the left anterior descending coronary artery relative to saphenous vein bypass grafting, subsequent studies have reported greater survival advantage with BITA. ${ }^{11-13}$ Notwithstanding, the reluctance to use BITA routinely rather than single LITA continued to persist, ${ }^{14-16}$ with the greatest concerns relating to increased risk of deep sternal wound infection, especially in patients with severe chronic diabetes. ${ }^{16,17}$ Itagaki and colleagues, ${ }^{15}$ however, showed BITA use not to be an overall independent predictor of deep sternal wound infection, and increasingly the significantly enhanced long-term survival benefit associated with BITA is being reported to far outweigh the short-term morbidity of deep sternal wound infection. ${ }^{16,18}$ Consistent with these studies, the study in this issue also showed a survival advantage with BITA, but the greater mean anastomosis number with BITA relative to single LITA made it difficult to distinguish the beneficial effects afforded by the superior completeness in revascularization from the arterial nature of BITA grafting itself. Theoretically, the venous nature of the saphenous 
vein graft places it at a disadvantage relative to arterial grafts, but factors such as the grafting technique (individual vs sequential bypass grafting) and the various harvesting techniques (endoscopic vs open technique, skeletonization vs harvesting with fat, predilation, etc) have been reported to have significant implications for long-term graft patency, ${ }^{17-23}$ which if properly addressed may potentially level the playing field. From this perspective, the verdict is still out, and the bottom line regarding the single most important surgical objective in CABG remains achieving complete revascularization. Finally, even the best matched propensity studies, such as the report in this issue, cannot overcome the inability to balance for unmeasured covariates. It therefore is to be hoped that the outcomes of the ART, ${ }^{24}$ which is the first and so far only prospective, randomized clinical trial to compare BITA with single LITA will help to resolve the debate regarding the optimal conduit choice for CABG.

\section{References}

1. Grau JB, Johnson CK, Kuschner CE, Ferrari G, Shaw RE, Brizzio ME, Zapolanski A. Impact of pump status and conduit choice in coronary artery bypass: A 15-year follow-up study in 1412 propensity-matched patients. J Thorac Cardiovasc Surg. 2015;149:1027-33.e2.

2. Shroyer AL, Grover FL, Hattler B, Collins JF, McDonald GO, Kozora E, et al; Veterans Affairs Randomized On/Off Bypass (ROOBY) Study Group. On-pump versus off-pump coronary-artery bypass surgery. N Eng J Med. 2009;361:1827-37.

3. Kim JB, Yun SC, Lim JW, Hwang SK, Jung SH, Song H, et al. Long-term survival following coronary artery bypass grafting: off-pump versus on-pump strategies. J Am Coll Cardiol. 2014;63:2280-8.

4. Takagi H, Yamamoto H, Iwata K, Goto SN, Umemoto T. Ask not which can impair early morbidity —ask which can improve late survival: a meta-analysis of randomized trials of off-pump versus on-pump coronary artery bypass. Int $J$ Cardiol. 2012;158:435-8.

5. Houlind K, Fenger-Grøn M, Holme SJ, Kjeldsen BJ, Madsen SN, Rasmussen BS, et al; DOORS Study Group. Graft patency after off-pump coronary bypass is inferior even with identical heparinization protocols: results from the Danish On-pump Versus Off-pump Randomization Study (DOORS). J Thorac Cardiovasc Surg. 2014;148:1812-9.e2.

6. Lamy A, Devereaux PJ, Prabhakaran D, Taggart DP, Hu S, Paolasso E, et al; CORONARY Investigators. Effects of off-pump and on-pump coronary-artery bypass grafting at 1 year. N Eng J Med. 2013;368:1179-88.

7. Taggart DP, Altman DG, Gray AM, Lees B, Nugara F, Yu LM, et al; on behalf of the ART Investigators. Effects of on-pump and off-pump surgery in the Arterial Revascularization Trial. Eur J Cardiothorac Surg. September 12, 2014 [Epub ahead of print].

8. Synnergen MJ, Ekroth R, Odén A, Rexius H, Wiklund L. Incomplete revascularization reduces survival benefit of coronary artery bypass grafting: role of offpump surgery. J Thorac Cardiovasc Surg. 2008;136:29-36.

9. Puskas JD, Williams WH, Duke PG, Staples JR, Glas KE, Marshall JJ, et al. Offpump coronary artery bypass grafting provides complete revascularization with reduced myocardial injury, transfusion requirements, and length of stay: a prospective randomized comparison of two hundred unselected patients undergoing off-pump versus conventional coronary artery bypass grafting. $J$ Thorac Cardiovasc Surg. 2003;125:797-808.

10. Loop FD, Lytle BW, Cosgrove DM, Stewart RW, Goormastic M, Williams GW, et al. Influence of the internal mammary artery graft on 10-year survival and other cardiac events. N Engl J Med. 1986;314:1-6.

11. Buxton BF, Ruengsakulrach P, Fuller J, Rosalion A, Reid CM, Tatoulis J. The right ITA graft-benefits of grafting the left coronary system and native vessels with a high grade stenosis. Eur J Cardiothorac Surg. 2001;18:255-61.

12. Taggart DP, D'Amico R, Altman DG. The effect of arterial revascularization on survival: a systematic review of studies comparing bilateral and single internal mammary arteries. Lancet. 2001;358:870-5.

13. Ioannidis JP, Galanos O, Katritsis D, Connery CP, Drossos GE, Swistel DG, et al Early mortality and morbidity of bilateral versus single internal thoracic artery revascularization: propensity and risk modeling. J Am Coll Cardiol. 2001;37: 521-8.

14. Bridgewater B, Keogh B; on behalf of the Society for Cardiothoracic Surgery in Great Britain and Ireland; Kinsman R, Walton P; Dendrite Clinical Systems. Sixth National Adult Cardiac Surgical Database report 2008: demonstrating quality. Henley-on-Thames, UK: Dendrite Clinical Systems; 2009. Available at: http:/ www.scts.org/_userfiles/resources/SixthNACSDreport2008withcovers.pdf.

15. Tabata M, Grab JD, Khalpey Z, Edwards FH, O’Brien SM, Cohn LH, et al Prevalence and variability of internal mammary artery graft use in contemporary multivessel coronary artery bypass graft surgery: analysis of the Society of Thoracic Surgeons National Cardiac Database. Circulation. 2009;120: 935-40.

16. Itagaki S, Cavallaro $\mathrm{P}$, Adams DH, Chikwe J. Bilateral internal mammary artery grafts, mortality and morbidity: an analysis of 1,526,360 coronary bypass operations. Heart. 2013;99:849-53.

17. Dai C, Lu Z, Zhu H, Lian F. Bilateral internal mammary artery grafting and risk of sternal wound infection: evidence from observational studies. Ann Thorac Surg. 2013;95:1938-45.

18. Benedetto U, Amrani M, Gaer J, Bahrami T, de Robertis F, Simon AR, et al. The influence of bilateral internal mammary arteries on short- and long-term outcomes: a propensity score matching in accordance with current recommendations. J Thorac Cardiovasc Surg. 2014;148:2699-705.

19. Kim HJ, Lee TY, Kim JB, Cho WC, Jung SH, Chung CH, et al. The impact of sequential versus single anastomosis on flow characteristics and midterm patency of saphenous vein grafts in coronary bypass grafting. J Thorac Cardiovasc Surg. 2011;141:750-4.

20. Li J, Liu Y, Zheng J, Bai T, Liu Y, Wang X, et al. The patency of sequency and individual vein coronary bypass grafts: a systematic review. Ann Thorac Surg. 2011;92:1292-8.

21. Lopes RD, Hafley GE, Allen KB, Ferguson TB, Peterson ED, Harrington RA et al. Endoscopic versus open vein-graft harvesting in coronary-artery bypass surgery. $N$ Engl J Med. 2009;361:235-44.

22. Souza DS, Johansson B, Bojö L, Karlsson R, Geijer H, Filbey D, et al. Harvesting the saphenous vein with surrounding tissue for $\mathrm{CABG}$ provides long-term graft patency comparable to the left internal thoracic artery: results of a randomized longitudinal trial. J Thorac Cardiovasc Surg. 2006;132:373-8.

23. Christenson JT, Schmuziger M. Sequential venous bypass grafts: results 10 years later. Ann Thorac Surg. 1997;63:371-6.

24. Taggart DP, Lees B, Gray A, Altman DG, Flather M, Channon K, ART Inves tigators. Protocol for the Arterial Revascularisation Trial (ART). A randomised trial to compare survival following bilateral versus single internal mammary grafting in coronary revascularisation [ISRCTN46552265]. Trials 2006;7:7. 